\title{
Growth rates of the two reef-building species, Acropora humilis and Millepora platyphylla at Hurghada, Red Sea, Egypt
}

\author{
Tamer M. Attalla ${ }^{1}$, Mahmoud H. Hanafy ${ }^{2}$, and Maher A. Aamer ${ }^{2}$ \\ 1- Red Sea National Parks, EEAA, Hurghada, Egypt. \\ 2- Marine Science Department, Faculty of Science, Suez Canal \\ University, 41552 Ismailia, Egypt \\ Corresponding author:maheraaziz@yahoo.com
}

\begin{abstract}
L inear growth rates were measured for two species of coral namely, Acropora humilis and Millepora platyphylla in Hurghada during the period from autumn 2006 to summer 2007. In addition, the rates of recovery in man-made lesion in M. platyphylla were estimated on seasonal basis. The linear growth rates of $A$. humils varied significantly according to the sheltering condition, with an overall mean of 8.89 and $6.98 \mathrm{~mm} /$ year in exposed and sheltered sites. The highest linear growth rate of $A$. humilis was estimated at the exposed site of Gotta Abu Ramada, being $9.17 \mathrm{~mm} /$ year, while the lowest rate of $6.61 \mathrm{~mm} /$ year was recorded at the sheltered site of El-Fanadir Reef. The seasonal linear growth rates of $M$. platyphylla were affected significantly by the sheltering condition, and non-significantly by seasons. The estimated annual growth rates of $M$. platyphylla at the exposed sites averaged higher value of $15.65 \mathrm{~mm} / \mathrm{year}$ compared to $11.29 \mathrm{~mm} / \mathrm{year}$ at the sheltered sites. On the seasonal level, the highest overall mean of growth rates was recorded in spring, while the lowest mean was in autumn, being 3.72 and $3.06 \mathrm{~mm} /$ season, respectively.

The rates of diametric lesions recovery of $M$. platyphylla varied significantly according to seasons and non-significantly according to sheltering condition. The fastest recovery was recorded in summer, while the lowest recovery was in winter. For instance, the lesions of $3847 \mathrm{~mm}^{2}$ area each, recovered completely within 6 weeks in summer, while the same lesions area were not recovered completely after 12 weeks in winter.
\end{abstract}

Keywords: Growth rates, Acropora humilis and Millepora platyphylla, Hurghada Egypt

\section{INTRODUCTION}

Skeletal growth of stony corals is one of the important ecological and biological parameters, which essentially can help as an indicator for the calcification rate of the reef. Measurement of skeletal linear extension (LE) of coral within a distinct period by means of skeletal markers are one of the methods used (Rahav et al., 1991; Dullo et al., 1995). Several methods have been used such as, plastic coated wires (Oliver, 1984), Alizarin-Red-S-stain in order to stain the respective coral colonies alive (Gladfelter, 1984; Dullo et al., 
1995), spikes were also driven into the coral skeleton as markers (Shinn, 1976) and direct interval photograph of the coral colonies have been used (Rahav et al., 1991) as well.

Along the Egyptian Red Sea coral reefs, few studies were achieved on some scleractinian growth. Kotb (1996) studied the linear growth rate of Acropora granulose and Stylophora pistillata by Alizarin Red method in southeastern coast of Sinai Peninsula. He also compared his data after 5 years (2001) in the same area, with the growth rate of another species (e.g. P. damicornis) by the same method. Al-Azri (1996) estimated the linear growth rate of A. granulosa and S. pistillata at Ras Mohammed. Ammar et al. (2000) made some measurements on transplanted A. humilis and S. pistillata, while Mohammed (2003) studied the linear growth rate of A. humilis and S. pistillata at the reef off Hurghada. More recently Aamer (2004) chosed four scleratinian species namely, Acropora humilis, Pocillopora damicornis, Pacillopora verrucosa and Stylophora pistillata to study the growth rate at six sites in Sharm El Sheikh.

The study of lesions recovery in corals is investigated fairly in many areas of the world except the Red Sea. Most of the research done on this subject has been carried out in Curacao (Meesters et al., 1994, 1996; 1997 Nagelkerken and Bak,1998), in Panama (Guzmán et al., 1994), in Florida (Hayes and Bush, 1990), in the Red Sea (Oren et al., 1998 ) and in Australia (Hall, 1997). Woesik (1998) compared the lesion healing capability in Porites lutea and P. lobata corals from Japan, but he found no differences in tissue regeneration between these two species.

This present study aimed to investigate the linear growth rates of the two species Acropora humilis and Millepora platyphylla and the rate of lesions recovery in $M$. platyphylla. In addition, the study attempted to study the environmental conditions (i.e. sheltering and exposure condition) on their growth rates during a whole year in $A$. humilis and in different seasons in $M$. platyphylla.

\section{MATERIAL AND METHODS}

The linear growth rates of the two coral species Acropora humilis (Dana, 1846) and Millepora platyphylla (Hemprich \& Ehrenberg, 1834), as well as the recovery of man-made lesions in $M$. platyphylla were estimated on seasonal basis in Hurghada during the period from autumn 2006 to summer 2007. The linear growth rates for $A$. humilis were estimated at eight exposed and sheltered sites (namely; Gotta Abu Ramada, El Fanous, Carless Reef and Umm Gammer Is., as exposed sites and Small Giftun Is., Sabina Reef, Ishtta Reefs and El- Fanadir Reef, as sheltered sites), (Fig. 1). Except the two sites of Carless Reef and Umm Gammer Is., the linear growth rates in M. platyphylla were estimated in the other 6 sites.

At each site at $5 \mathrm{~m}$ depth, five colonies of each species were selected and marked. In A. humilis five branches for each colony were selected randomly and 
tagged by plastic string at approximately $1.5-2.0 \mathrm{~cm}$ apart from the branch tip. In case of $M$. platyphylla, the plate of each selected colony was tagged by plastic string at $4.0-5.0 \mathrm{~cm}$ apart from the plate tip.

The linear extensions (growth) of each branch or plate were measured annually in case of $A$. humilis and seasonally in $M$. platyphylla (between autumn 2006 and summer 2007). In both species, the linear extension was as shown in Fig. (2).

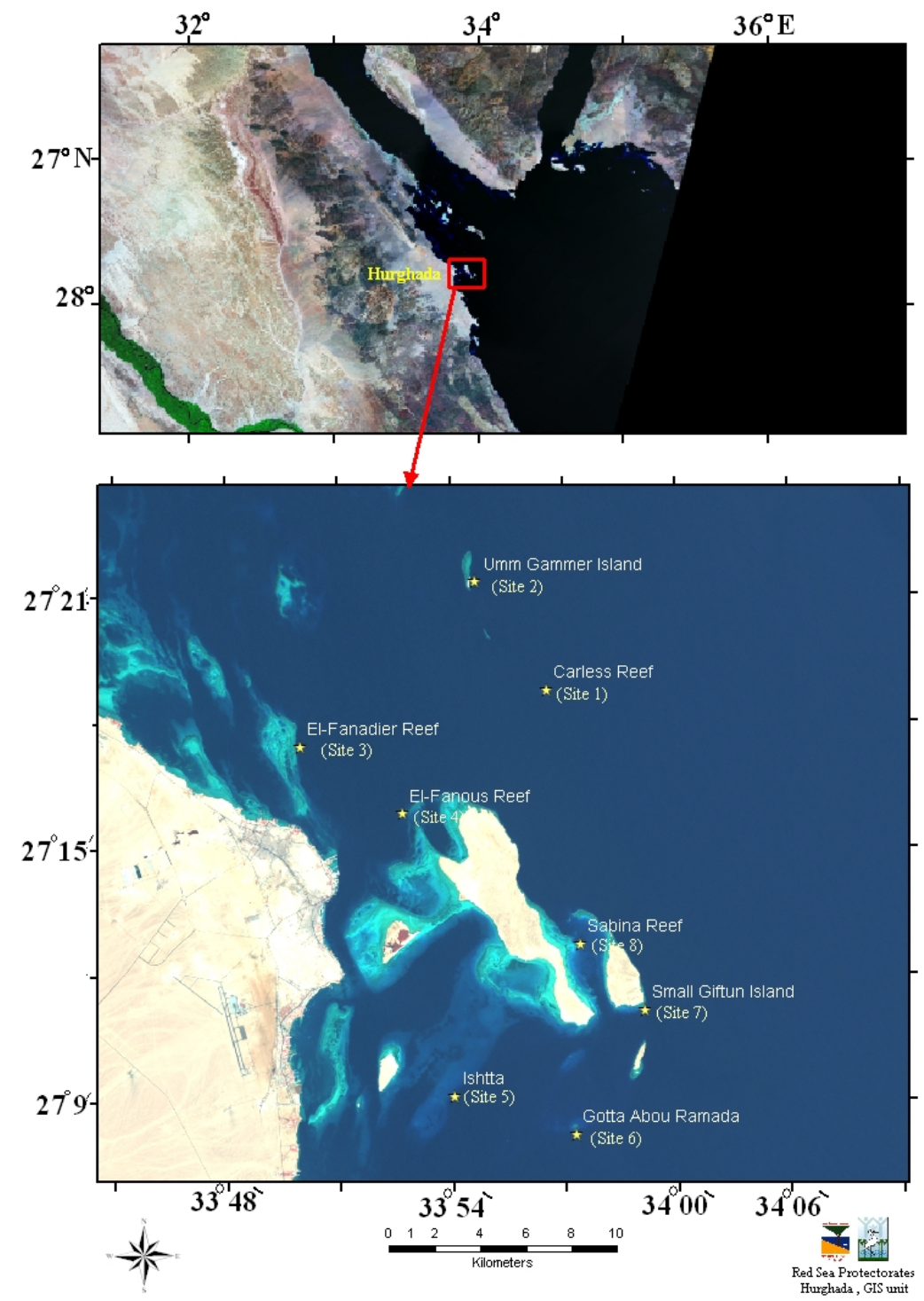

Fig. 1: Satellite map of the total eight studied sites around Hurghada area. 


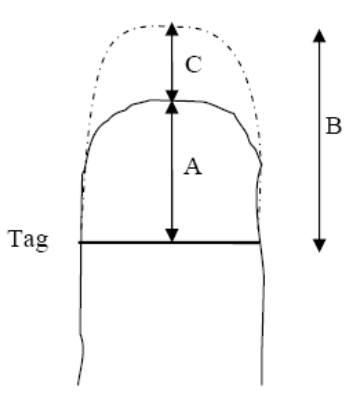

$\mathrm{A}=$ distance between tag position and tip at starting point.

$\mathrm{B}=$ distance between tagging point and tip after the growth period.

$\mathrm{C}=$ grown distance $/$ growing period $=\mathrm{B}-\mathrm{A}$.

Fig. 2: Estimate of the linear growth rates in both species

An experiment was designed on seasonal basis to measure the rate of recovery in lost tissue in $M$. platyphylla, which could be occurred due to bioerosion or potential damage as a result of divers contact. For this purpose, five colonies of $M$. platyphylla were selected at two sites (Gotta Abu Ramada and Sabina Reef) and at $5 \mathrm{~m}$ depth. A circle lesion of $70 \mathrm{~mm}$ diameter with $3847 \mathrm{~mm}^{2}$ areas was made artificially using sharp blade on a selected plate per colony. On bi-weekly intervals, the recovery rates were measured as the length of growing tissue on the diametric axis of the lesion, using a Verner caliper to the nearest $0.01 \mathrm{~mm}$, and as the area of grown tissue on the lesion (Fig. 3). To determine the seasonal variation on recovery, the experiment was repeated on seasonal basis starting from winter 2007 to autumn 2007.

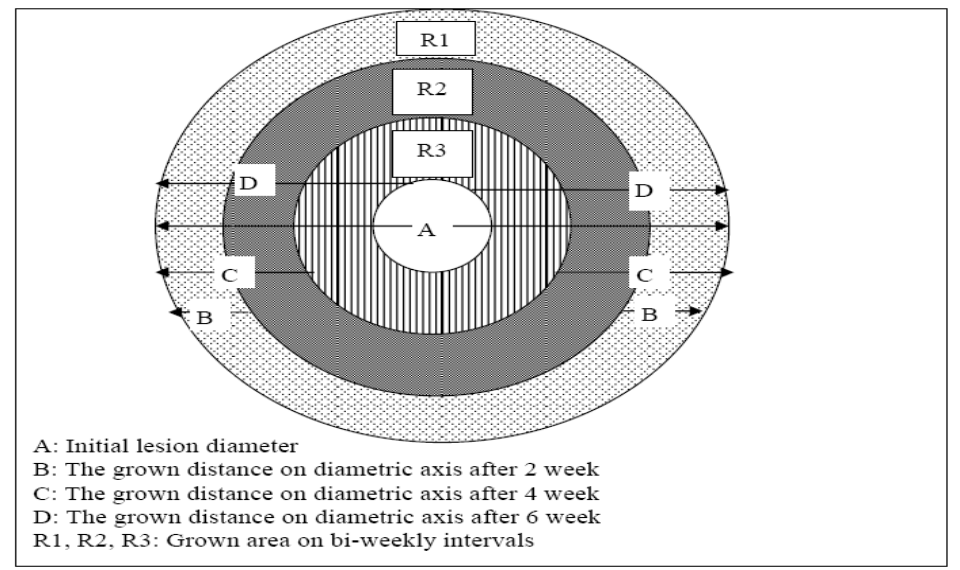

Fig. 3: Estimate of recovery rates in M. platyphylla 


\section{RESULTS}

The linear growth rates of A.humils varied significantly according to sheltering condition and sites, $(\mathrm{P}<0.001)$. The estimated linear growth rate of $A$. humilis in the study area recorded higher values at exposed sites, with an overall mean of $8.89 \mathrm{~mm} /$ year, compared to $6.97 \mathrm{~mm} /$ year estimated for sheltered sites. In general, the highest linear growth rate of $A$. humilis was estimated at the exposed site of Gotta Abu Ramada, $(9.17 \mathrm{~mm} / \mathrm{year})$, while the lowest rate of $6.61 \mathrm{~mm} /$ year was recorded at the sheltered site of El-Fanadir Reef (Table 1).

Table 1: Mean growth rates of Acropora humilis (mm/year) recorded at the selected exposed and sheltered studied sites

\begin{tabular}{|l|c|}
\hline \multicolumn{1}{|c|}{ Sites } & Average linear growth rate $\mathbf{~ m m}$-year \\
\hline \multicolumn{1}{|c|}{ Exposed sites } & 9.17 \\
\hline Gotta Abu Ramada & 8.91 \\
\hline El-Fanous Reef & 8.81 \\
\hline Carless Reef & 8.66 \\
\hline Umm Gammer Island & $\mathbf{8 . 8 9}$ \\
\hline Mean & \\
\hline \multicolumn{1}{|c|}{ Sheltered sites } & 6.85 \\
\hline Small Giftun Island & 7.1 \\
\hline Sabina Reef & 7.35 \\
\hline Ishtta Reef & 6.61 \\
\hline El-Fanadir Reef & $\mathbf{6 . 9 7}$ \\
\hline Mean &
\end{tabular}

The seasonal linear growth rates of Millepora platyphylla were affected significantly by sheltering condition, $(\mathrm{p}=0.006)$, and non-significantly by seasons, $(\mathrm{p}=0.292)$. The annual growth rates of M. platyphylla at the exposed sites averaged higher value of $15.65 \mathrm{~mm} /$ year rather than the value averaged at the sheltered sites $(11.29 \mathrm{~mm} /$ year $)$ as given in Table (2).

On the seasonal level, the highest overall mean of growth rates was recorded during spring, while the lowest mean was during autumn (i.e. 3.72 and $3.06 \mathrm{~mm} / \mathrm{season}$, respectively), (Table 2). Among all sites, the highest growth rates of M. platyphylla were recorded at the exposed reef of Gotta Abu Ramada site in all seasons (ranged between 3.85 and $4.53 \mathrm{~mm} / \mathrm{season}$ in autumn and spring, respectively). In comparison, the lowest growth rates were estimated at sheltered reefs of El-Fanadir Reef in all seasons (ranged between 2.13 and $2.97 \mathrm{~mm} /$ season in autumn and spring, respectively (Table 2 and Fig. 4). 
Table 2: Seasonal and annual linear growth rates $(\mathrm{mm})$ of $M$. platyphylla recorded at the sheltered and exposed sites

\begin{tabular}{|c|c|c|c|c|c|}
\hline Sites & Autum $2006 / \mathrm{mm}$ & Winter $2007 / \mathrm{mm}$ & Spring $2007 / \mathbf{m m}$ & Summer $2007 / \mathrm{mm}$ & $\begin{array}{c}\text { Annual growth rate } \\
\mathrm{mm} / \text { year }\end{array}$ \\
\hline \multicolumn{6}{|l|}{ Exposed sites } \\
\hline Gotta Abu Ramada & 3.85 & 4.08 & 4.53 & 4.23 & 16.69 \\
\hline El-Fanous Reef & 3.50 & 3.70 & 3.90 & 3.50 & 14.60 \\
\hline Mean & 3.68 & 3.89 & 4.22 & 3.87 & 15.65 \\
\hline \multicolumn{6}{|l|}{ Sheltered sites } \\
\hline Ishtta Reef & 2.58 & 2.88 & 3.35 & 2.90 & 11.71 \\
\hline Sabina Reef & 2.58 & 2.83 & 3.25 & 2.98 & 11.64 \\
\hline Small Giftun Island & 2.50 & 2.80 & 3.30 & 2.97 & 11.57 \\
\hline El-Fanadir Reef & 2.13 & 2.47 & 2.97 & 2.67 & 10.24 \\
\hline Mean & 2.45 & 2.75 & 3.22 & 2.88 & 11.29 \\
\hline Overall means & 3.06 & 3.32 & 3.72 & 3.37 & 13.47 \\
\hline
\end{tabular}

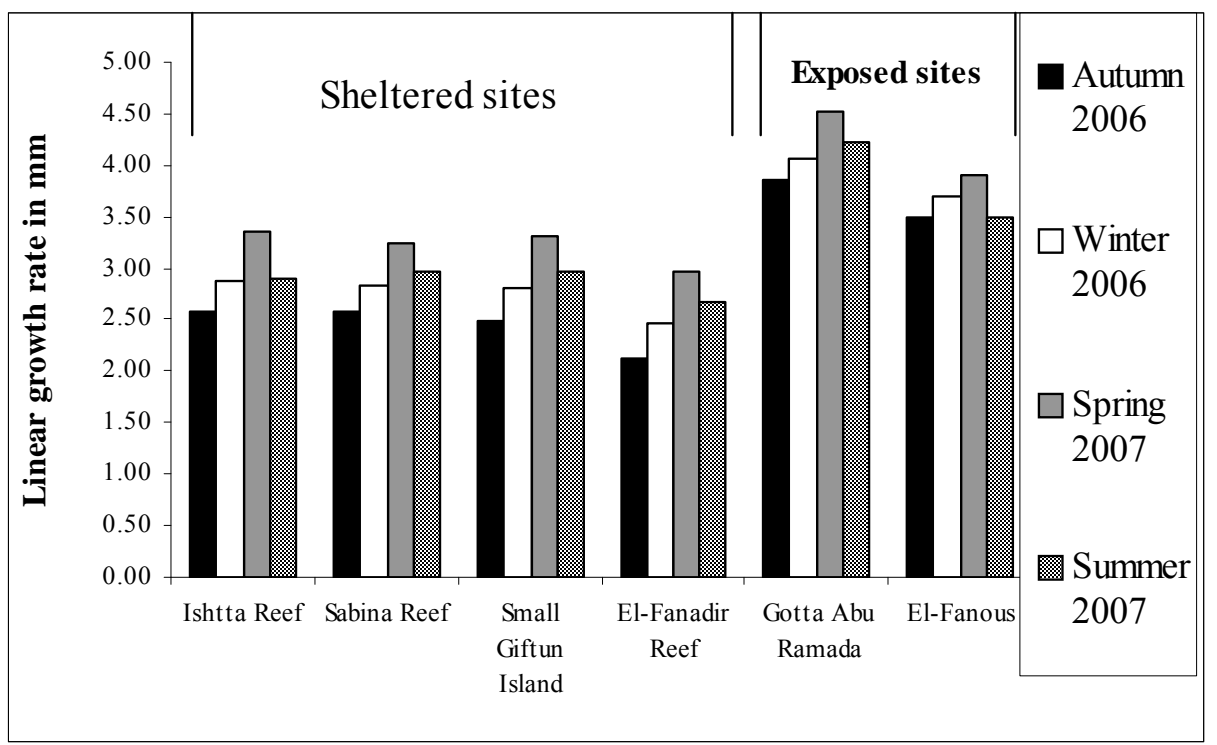

Fig. 4: Mean linear growth rates ( $\mathrm{mm} /$ season) of $M$. platyphylla estimated for different seasons at different study sites.

The progress in the recovery of the artificially made lesions on the plates of $M$. platyphylla is shown in Fig. (5). The seasonal rate of recovery varied significantly according to seasons, $(\mathrm{p}<0.001)$ and non-significantly according to sheltering condition, $(\mathrm{p}=0.834)$. According to seasons, the highest recovery rates at the two sites occurred during summer, where all lesions recovered in six weeks. In contrast, the lowest recovery rates were recorded during winter, where 
there was no complete recovery after a trial period of 12 weeks (Fig. 6 and Table $3)$. This allowed algae to be grown in center of the lesions.

In winter, the diametric recovery rates of $M$. platyphylla at sheltered site of Sabina Reef was found to be higher during the first 10 weeks than that recorded at the exposed site of Gotta Abu Ramada. During the last two weeks, there was no recording for growth at both sites (Fig.6). The higher bi-weekly diametric recovery rates at both sites recorded in the eighth week were 15.99 and $16.83 \mathrm{~mm}$ at Gotta Abu Ramada and Sabina Reef respectively (Table 3).

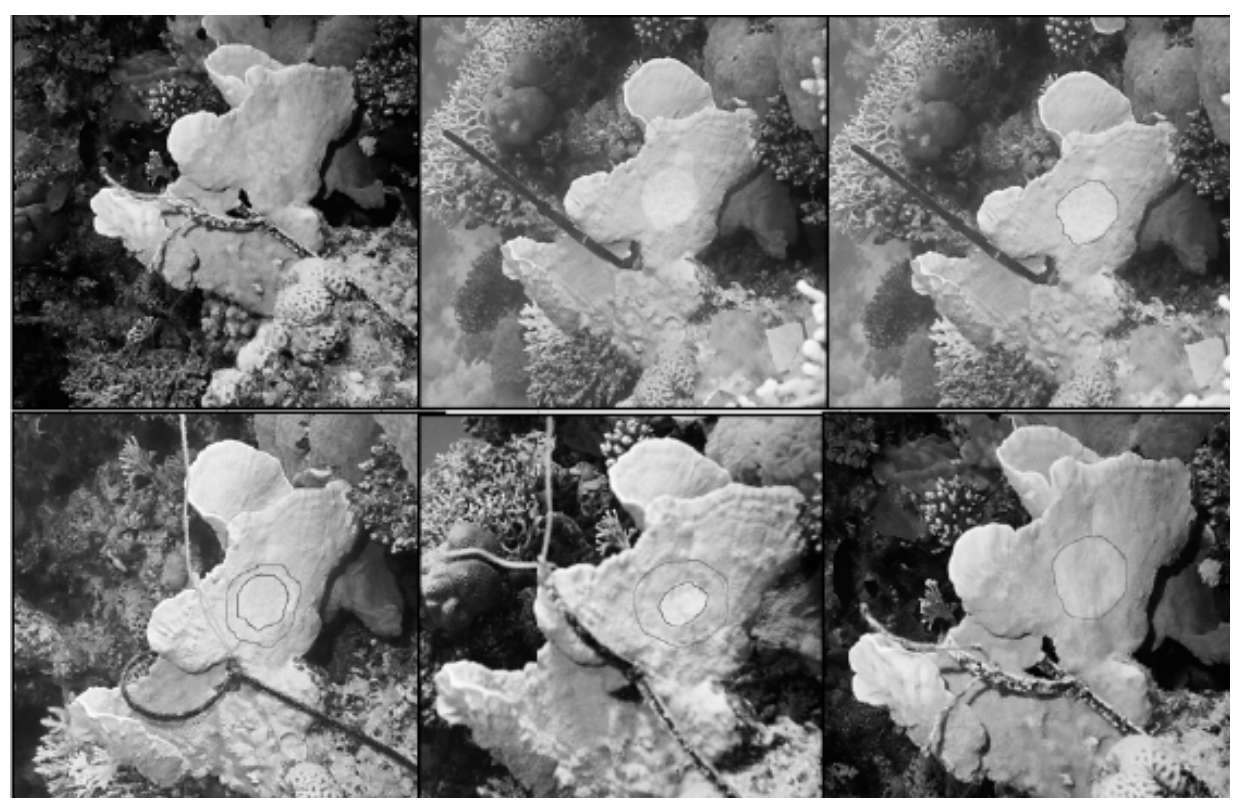

Fig.6: The recovery progress in artificially made lesions on the plates of M. platyphylla

Table 3: Seasonal diametric recovery rates in artificially made scars on M. platyphylla plates measured bi-weekly. (Initial lesion 70mm diameter)

\begin{tabular}{|c|c|c|c|c|c|c|c|}
\hline \multirow{2}{*}{ Seasons } & \multirow{2}{*}{ Sites } & \multicolumn{6}{|c|}{ Rate of recovery (weeks) } \\
\cline { 3 - 8 } & & $\mathbf{2}$ & $\mathbf{4}$ & $\mathbf{6}$ & $\mathbf{8}$ & $\mathbf{1 0}$ & $\mathbf{1 2}$ \\
\hline \multirow{3}{*}{ Winter 2007 } & Gotta Abu Ramada & 5.35 & 5.76 & 8.76 & 15.99 & 10.36 & 0.00 \\
\cline { 2 - 8 } & Sabina Reef & 6.45 & 6.96 & 10.67 & 16.83 & 8.18 & 0.00 \\
\hline \multirow{2}{*}{ Spring 2007 } & Gotta Abu Ramada & 5.12 & 6.72 & 10.90 & 23.64 & 15.98 & 7.64 \\
\cline { 2 - 8 } & Sabina Reef & 5.56 & 5.79 & 33.39 & 20.07 & 5.19 & \\
\hline \multirow{2}{*}{ Summer 2007 } & Gotta Abu Ramada & 26.80 & 24.33 & 18.87 & & & \\
\cline { 2 - 8 } & Sabina Reef & 32.53 & 21.31 & 16.16 & & & \\
\hline \multirow{2}{*}{ Autumn 2007 } & Gotta Abu Ramada & 39.15 & 20.57 & 7.58 & 2.71 & & \\
\cline { 2 - 8 } & Sabina Reef & 58.42 & 7.96 & 3.08 & 0.54 & & \\
\hline
\end{tabular}


Lesion recovery in spring at Sabina Reef was found to be faster than at Gotta Abu Ramada as it took ten weeks to recover the entire lesion at Sabina Reef, while it took 12 weeks at Gotta Abu Ramada (Fig.6). The bi-weekly diametric recovery rates were recorded with higher value in the sixth week at Sabina Reef and in the eighth week at Gotta Abu Ramada, being 33.39 and $23.64 \mathrm{~mm}$, respectively (Table 3 ).

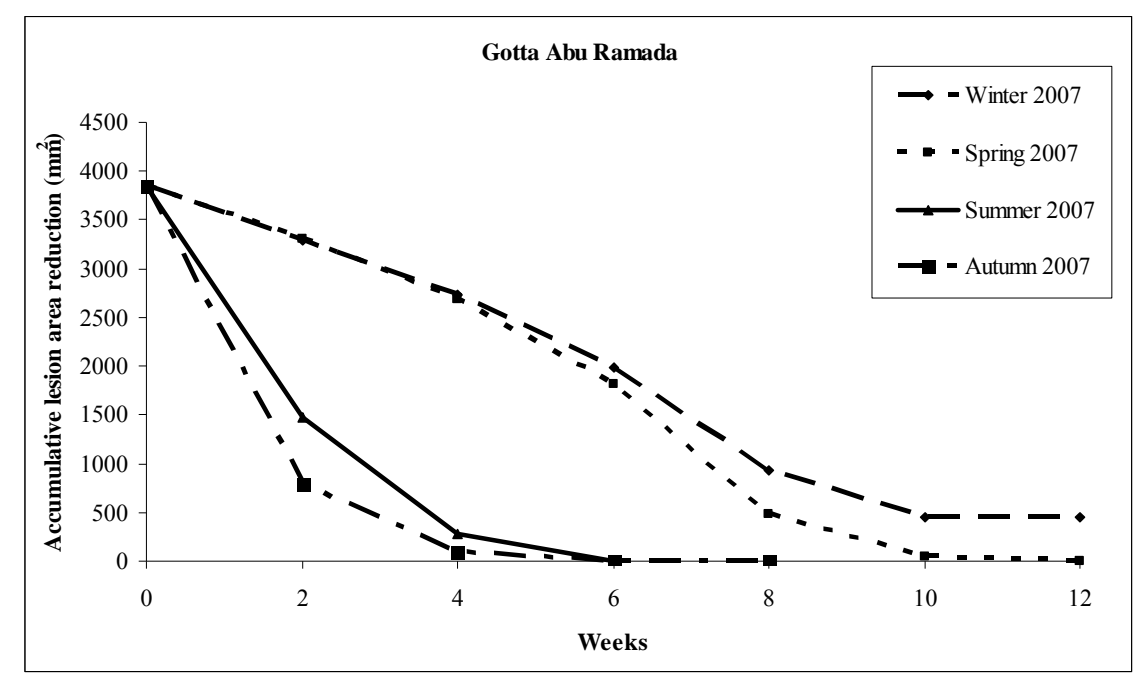

(A)

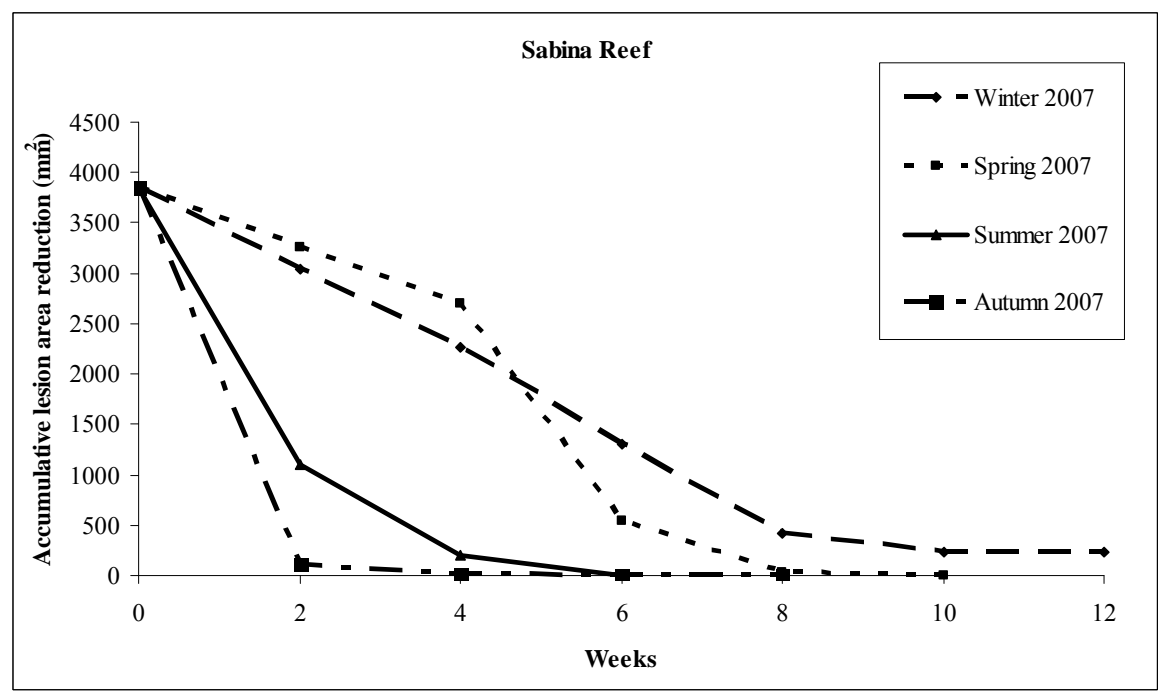

(B)

Fig. 5: Accumulative reduction in the area of artificially made lesions on $M$. platyphylla bi-weekly during different seasons at Gotta Abu Ramada (A) and Sabina Reef (B) 
During summer, complete recovery of the lesions occurred within 6 weeks at both sites, (Fig.6). The higher bi-weekly diametric recovery rates at the two sites were recorded in the second week being 26.80 and $32.53 \mathrm{~mm}$ at Gotta Abu Ramada and Sabina Reef, respectively, with an average value of $23.3 \mathrm{~mm} / 2$ weeks (Table 3 ).

The recovery during autumn took eight weeks to recover the entire lesion at both sites. The diametric recovery rate of M. platyphylla in Sabina Reef was found to be slightly higher than at Gotta Abu Ramada (Fig.6). Higher bi-weekly diametric recovery rates at both sites were recorded in the second week, being 39.15 and $58.42 \mathrm{~mm}$ at Gotta Abu Ramada and Sabina Reef, respectively, with an average value of $17.5 \mathrm{~mm} / 2$ weeks (Table 3 ).

\section{DISCUSSION}

Coral growth rate is variable between different species on all accessible time scales; hours to days, weeks to months and seasons to years (Goreau, 1959). It is known that annual coral growth can be affected by different physical factors such as temperature (Gladfelter, 1984; Wellington \& Dunbar, 1995 Kotb, 2002; Aamer, 2004), light and depth "as a function of light intensity" (Fricke \& Schumacher, 1983; Wellington and Glynn, 1983; Strämgren, 1987; Dullo et al., 1995; Aamer, 2004), salinity (Glynn, 1993), sedimentation rates (Charuchinda and Hylleberg, 1984; Hodgson \& Carperter, 1995; Aamer, 2004). In addition, water motion exerts a control over reef corals in various ways. Enhanced circulation (flushing) caused by waves, tides and currents modifies many important environmental factors (e.g. Plankton, dissolved nutrients, gases, sediment, water clarity, substrata, salinity, and temperature) which influence the coral growth and distribution (Graus et al., 1977; and Brown et al., 1985).

The linear growth rates of $A$. humilis varied significantly according to the sheltering condition, $(\mathrm{P}=0.001)$ and sites, $(\mathrm{P}=0.001)$. The annual mean growth rates of $A$. humilis ranged between $6.61 \mathrm{~mm} /$ year and $9.17 \mathrm{~mm} /$ year. Slightly lower rates of 6.8 and $7.4 \mathrm{~mm} /$ year were recorded by Mohammed (2003) for the same species on selected reefs off Hurghada. Ammar et al. (2000) estimated growth rates of 3 to $7 \mathrm{~mm} /$ year in the transplanted $A$. humilis at the same localities. Aamer (2004) concluded that sites or location influenced significantly the linear growth rates of A. humilis at Sharm El-Shiekh which ranged between $6.17 \mathrm{~mm} /$ year and $9.80 \mathrm{~mm} /$ year, while Davies, (1989) found that A. humilis in Caribbean Sea varied between $2-13.3 \mathrm{~mm} /$ year at $2 \mathrm{~m}$ depth.

The linear growth rates of $A$. humilis were affected by the sheltering condition, where higher growth rates were recorded at the exposed sites of Gotta Abu Ramda. This likely results from water movement which is higher in exposed sites than in sheltered sites, which provided food (nutrients and plankton) to corals in exposed condition rather than corals in sheltered condition. Riegl and Velimirov (1994) and Riegl and Piller (1997) studied the structure of the coral communities at Hurghada in northern Red Sea and concluded that, 
coral communities are dominated by A. hyacinthus, A. humilis, Millepora sp. and Stylophora pistilata at $10 \mathrm{~m}$ depth of the exposed reefs, while the sheltered sites were dominated by Porites sp. Exposed reefs, dominated by Acropora sp. have been described from the central Red Sea in Sudan (Mergner\& Schuhmacher 1985; Head, 1987), from the Indian Ocean in Chagos (Sheppard, 1980) and in Madagascar (Pichon, 1978) and from the Pacific in the Great Barrier Reef (Wallace, 1978; Done, 1982).

The linear growth rates of $M$. platyphylla were influenced significantly by sheltering condition. Very few studies were carried on $M$. platyphylla growth rates, and some of these studies showed that $M$. platyphylla are built of well calcified basal plates of the colonies, which are strengthened by multiple fusions (Riegl and Piller, 1997;1999). This may support the finding of this study, where higher growth rates of $M$. platyphylla were recorded at the exposed sites than in shelter sites. Also Riegl and Velimirov (1994) found that one of the most dominant species of exposed sites in the Red Sea was Millepora sp. In the Caribbean Sea, Geister (1983) found coral framework in the sites frequently exposed to high hydrodynamic forces dominated by Acropora sp. and Millepora sp.

The present results show non-significant differences at the seasonal variation. The highest average growth rates were recorded at spring. Soonge and Cho (1998) demonstrated the release of medusae of three hydrozoan fire corals namely, Millepora dichotoma, M. murrayi and $M$. platyphylla at three sites in southern Taiwan from February 1994 to July 1995. All the three species were gonochoristic, which developed and released several batches of medusae between April and May and the earliest medusae appearing in March. For the plate-like $M$. platyphylla at Wanliton, the first batch of medusae, averaging $0.26 \mathrm{~mm}$ in diameter, was observed in tissues on April 7, 1995. The medusa reached an average maximum diameter of $0.62 \mathrm{~mm}$ by the end of April.

The rate of recovery of $M$. platyphylla varied significantly according to seasons, and non-significantly according to sheltering condition. The highest recovery rates at both sites occurred during summer and the lowest during winter. This is likely to be related to the expected higher temperature, light and food availability during summer time. Generally the growth of corals depends on temperature and light (Loya, 1985; Dotan, 1990; Kotb 1996; Ammar et al., 2000; Mohammed, 2003; and Aamer, 2004). The temperature increases the recovery of coral and reduces the growth of algae on the artificially made lesions. Cróquer et al. (2002) concluded that the recovery of Montastraea annularis (Faviidae) reaches its maximum with high temperature.

Serour (2004) estimated the potentially physical damage to corals by a diver at a rate of 3.87 incidents/dive. In 2008, almost more than 8 million dives have been recorded in the Egyptian coast of the Red Sea (Center for information and decision support in Red Sea Governorate). This means that, in total 30.9 millions potentially damaged incidents to corals occurred in 2008 . Therefore, in 
conclusion, $M$. platyphylla has the ability to regenerate damaged tissue fairly rapidly. In area such as reefs off Hurghada, where most reefs are heavily used by divers, such finding is so fortunate. It is indicated that the physical damage caused by divers for the plates of $M$. playphylla can be recovered completely within 6 weeks in summer and 12 weeks or slightly more in winter.

\section{REFERENCE}

Aamer, M.A.A., (2004). The role of zooplankton and water quality on some biological and ecological aspects of corals along the Egyptian Red Sea coast. A Ph.D. Thesis, Suez Canal University, Ismailia, Egypt; 325 pp.

Al-Azri, A. N. (1996). Some ecological studies of coral reefs of the Gulf of Aqaba (South Sinai). M.Sc. Thesis, Fac. Sci., Suez Canal Univ.

Ammar, M. S. A.; Amin, E. M.; Gundacker, D.; and Mueller, W. E. (2000). One rational strategy for restoration of coral reefs: Application of molecular biology tools to select sites for rehabilitation by asexual recruits. Mar. Pollut. Bull., 40, 7, 618-627.

Brown, B. E.; Sya'rani, L. and Le Tissier, M. D. (1985). Skeletal form and growth in Acropora aspera (Dana) from Pulau Seribu, Indonesia. J. Exp. Mar. Ecol., 86, 139-150.

Charuchinda, M. and Hylleberg, J. (1984). Skeletal extension and banding formation of Porites lutea of fringing reefs along the south and west coasts of Phuket Island (Thailand). Proc. 5th Int. Coral Reef Cong., Tahiti, 6, 83-87.

Cróquer, A., Villamizar, E., and Noriega, N., (2002). Environmental factors affecting tissue regeneration of the reef-building coral Montastraea annularis (Faviidae) at Los Roques National Park, Venezuela. Rev Biol. Trop 50: 1055-1065.

Davies, P. S. (1989): Short-term growth measurements of corals using an accurate buoyant weighing technique. Mar. Biol., 101, 389-395.

Done, T.I., (1982). Patterns in the distribution of coral communities across the Great Banier Reef. Coral Reefs, 1: 95-107.

Dotan, A. (1990). Population structure of the echinoid Heterocentrotus mammillatus (L.) along the littoral zone of south-eastern Sinai. Coral Reefs, 9, 75-80.

Dullo, W.; Gektidis, M.; Golubic, S.; Heiss, G.; Kampmann, H.; Kiene, W.; Kroll, D.; Kuhrau, M.; Radtke, G.; Reijmer, J.; Reinicke, G.; Schlichter, D; Schuhmacher, H. and Vogel, K. (1995). Factors controlling Holocene reef growth: An interdisciplinary approach. Facies, 32, 145-188.

Fricke, H.W. and Schuhmacher, H. (1983). The depth limits of Red Sea stony corals, an ecophysiological problem (A deep diving survey by submersible). P. S. Z. N. I., Marine Ecology, 4 (2): 163-194.

Geister, J., (1983). Holocene West Indian coral reefs: geomorphology, ecology and facies. Facies 9:173-284. 
Gladfelter, E. H. (1984). Skeletal development in Acropora cervicornis: IIIA comparison of monthly rates of linear extension and calcium carbonate accretion measured over a year. Coral Reefs, 3, 51-57.

Glynn, P.W. (1993). Coral reef bleaching, Ecological perspectives, Coral Reefs, $12(1): 1-17$.

Goreau, T. F. (1959). The physiology of skeleton formation in corals 1. A method for measuring the rate of calcium deposition by corals under different conditions. Biol. Bull.,166, 59-75.

Graus, R. R., Chambenlain, J. A. and Barker, A. M., (1977). Structural modification of corals in relation to wave and currents. Am. Ass. Petr. Geol. Tuka Oklahoma, pp, 135-153.

Guzmán, H.M., Burns, K.A., and Jackson, J.B.C., (1994). Injury regeneration and growth of Caribbean reef corals after a major oil spill at Panamá. Mar. Ecol. Prog. Ser. 105: 231-241.

Hall, R.V., (1997). Interspecific differences in the regeneration of artificial injuries on scleractinean corals. J. Exp. Mar. Biol. Ecol. 212: 9-23.

Hayes R.L. and Bush, P.G. (1990). Microscopic observations of recovery in the reefs building scleractinean coral Montastraea annularis after bleaching en a Cayman reef. Coral Reefs 8: 203-209.

Head, S. M., (1987) Corals and coral reefs of the Red Sea. In Edwards, A.J. and Head, S.M. (Eds.), Red Sea -Key Environments. Pergamon Press Oxford: 128-151.

Hodgson, G. and Carpenter, K. (1995). Scleractinian corals of Kuwait, Pacific Science, 49 (3): 207-226.

Kotb, M. A. (1996). Ecological and biological studies on the coral reefs at southern Sinai coasts, Red Sea, Egypt. Ph. D. Thesis. Marine Science Dept. F. Scie. Suez Canal Univ.

Kotb, M. .A. (2002). Skeletal density of the reef-building coral species in the Northern Red Sea. J. Egypt. German Society of Zoology. Invertebrate Zoology and Parasitology. Vol. 39 D: 1-16.

Loya, Y. (1985). Seasonal changes in growth rate of the Red Sea coral population. Proc. $5^{\text {th }}$ Int. Coral Reef Cong., Tahiti., 6, 187-191.

Meesters, E.H., Noordeloos, M. and Bak, R.P.M., (1994). Damage and regeneration: links to growth in the reef building coral Montastraea annularis. Mar. Ecol. Prog. Ser. 112: 119-128.

Meesters, E.H., Pauchli, W. and Bak, R.P.M. (1997). Predicting regeneration of physical damage on a reef - building coral by regeneration capacity and lesion shape. Mar. Ecol. Prog. Ser. 146: 91-99.

Meesters, E.H., Wesseling, I. and Bak, R.P.M., (1996). Partial mortality in three species of reef building corals and its relation with colony morphology. Bull. Mar. Sci. 58: 838-852.

Mergner, H. and Schuhmacher, H.(1985). Quantitative analysis of coral communities on Sanganeb Atoll (central Red Sea). Comparison with 
Aqaba reefs (northern Red Sea). Proc. 5th Int. Coral Reef Symp., Tahiti, Vol.6: 243-248.

Mohammed, T. A. (2003). Study of growth and reproduction of some corals at Hurghada region with reference to the effect of some pollutants in the area. Ph.D. Thesis, Fac. Sci. Suez Canal Univ., Egypt.

Nagelkerken, I. and Bak, R.P.M., (1998). Differential regeneration of artificial lesions among sympatric morphs of the Caribbean corals Porites astreoides and Stephanocoenia michelinii. Mar. Ecol. Prog. Ser. 163: $279-283$

Oliver, J. K. (1984). Intra-colony variation in the growth of Acropora Formosa: Extension rates and skeletal structure of white (Zooxanthellae free) and brown-tipped branches. Coral Reefs, 3, 139-147.

Oren, U., Benayahu, Y., Lubinevsky, H., and Loya, Y., (1998). Effect of lesion size and shape on regeneration of the Red Sea coral Faviafavus. Mar. Ecol. Prog. Ser. 146: 101-107.

Pichon, M., (1978). Recherches sur les peuplements a dominance d'anthozoaires dans les recifs corallines de Tulear (Madagascar). Atoll Res. Bull., 222; $445 \mathrm{pp}$.

Rahav, O.; Ben-Zion, M.; Achituv, Y. and Dubinsky, Z., (1991). A photographic, computerized method for in situ growth measurements in reef building cnidarians. Coral Reef., 9: 204.

Riegl, B. and Piller, W.E. (1997). Distribution and environmental control of coral assemblages in northern Safaga Bay (Red Sea, Egypt). Facies. Vol. $36,141-162$.

Riegl, B. and Piller, W.E. (1999). Coral frameworks revisited - reefs and coral carpets in the northern Red Sea. Coral Reefs. Vol. 18, 241-253.

Riegl, B., and Velimirov, B. (1994). The structure of coral communities at Hurghada in the Red Sea. P.S.Z.N.I: Mar Ecol 15(3/4) : 213-231.

Serour, R.K. (2004). An environmental economic assessment of the impacts of the recreational SCUBA diving on coral reef system in hurghada, the Red Sea, Egypt. M.Sc. Thesis University of Maryland, USA, PP 76.

Sheppard, C. R. C., (1980). Coral cover, zonation and diversity on reef slopes of Chagos Atoll and population structure of the major species. Mar. Ecol. Progr. Ser., 2: 193-205.

Shinn, E. A. (1976). Coral reef recovery in Florida and the Persian Gulf. Env. Geol., 1: 241-254.

Soonge, G.K., and Cho, L.C., (1998). Synchronized release of medusae from three species of hydrozoan fire corals. Coral Reefs (1998) $17: 145-154$.

Strämgren, T. (1987). The effect of light on the growth rate of intertidal Acropora pulchra (Brook) from Phukrt, Thailand, lat. 8ःN. Coral Reefs, 6, 43-47. 
Wallace., C., (1978). The coral genus Acropora (Scleractinia: Astrocoeniina: Acroporidae) in the central and southern Great Barrier Reef Province. Mem. Qld. Mus., 18 (2): 279-319, pIs. 43-104.

Wellington, G.M. and Dunbar, R.B. (1995). Stable isotopic signature of Elninosouthern oscillation events in eastern tropical pacific reef corals, Coral Reefs, 4: 5-25.

Wellington, G. M. and Glynn, P. W. (1983). Environmental influences on skeletal banding in eastern pacific reef (Panama) corals. Coral Reefs, 1, 215- 222.

Woesik, R.V. (1998). Lesion healing on massive Porites spp. corals. Mar. Ecol. Prog. Ser. 164: 213-220. 